\title{
Credit Risk Management and the Performance of Deposit Money Banks in Nigeria: An Error Correction Analysis
}

\author{
Ogbulu, Onyemachi Maxwell ${ }^{1} \&$ Eze, Gbalam Peter ${ }^{2}$ \\ ${ }^{1}$ Department of Banking and Finance, Abia State University, Uturu, Abia State. \\ ${ }^{2}$ Department of Finance and Accountancy, Niger Delta University, Wilberforce Island, Amassoma, Bayelsa State. \\ Correspondence: Ogbulu, Onyemachi Maxwell, Department of Banking and Finance, Abia State University, Uturu, \\ Abia State.
}

Received: December 21, 2015

Accepted: January 30, 2016

Available online: February 4, 2016

doi:10.11114/aef.v3i2.1356

URL: http://dx.doi.org/10.11114/aef.v3i2.1356

\begin{abstract}
.
This paper set out to investigate the impact of credit risk management on the performance of deposit money banks in Nigeria using the ECM and Granger causality techniques in addition to the IRF and VDC methodology. Data for the study were sourced from the CBN Statistical Bulletin and the Annual Reports and Accounts of the NDIC for the period 1989 to 2013. Our findings demonstrate succinctly that the selected credit risk management indicators under study significantly impact on the performance of deposit money banks measured as return on equity, return on total assets, and return on shareholders' fund respectively. However, the findings report no evidence of significant granger causality relationship between the various credit risk management indicators and the various measures of performance except for a uni-directional granger causality relationship from ROE to RNPD and from ROTA to RNPS respectively. Based on the foregoing, it is recommended that given the observed significant relation between credit risk management and performance, deposit money banks in Nigeria should always pay particular attention to their credit risk management policies in order to significantly improve on the performance of these banks.
\end{abstract}

Keywords: Credit Risk, Bank Performance, Error Correction Mechanism (ECM), Granger Causality and Variance Decomposition (VDC)

\section{Introduction}

Banks and other financial intermediaries play the important role of channelling funds from savers to borrowers. The traditional role of a bank is lending and loans make up the bulk of their assets. The various areas of financial management have been studied in relation to bank performance and growth usually depicted by profitability. Financial institutions (particularly deposit money banks) have faced difficulties over the years for a multitude of reasons and the major cause of serious banking problems continues to be directly related to lax credit standards for borrowers and counterparties, poor portfolio risk management, or lack of attention to changes in economic or other circumstances that can lead to a deterioration in the credit standing of a bank's counterparties (Gil-Diaz,1994). In unstable economic environments, bank earnings are fast overtaken by inflation and borrowers find it difficult to repay loans as real incomes fall, insider loans increase and over concentration in certain portfolios increases giving rise to credit risk. (Chen and Pan, 2012; Lindergren, 1987).

Bank failures in Nigeria and other emerging economies have been attributed to improper lending practices, lack of experience, organizational and informational systems to adequately assess credit risk in the falling economy (Gil-Diaz, 1994, Ahmad and Ariff, 2007; Kolapo, Ayeni and Oke, 2012). There is sufficient empirical evidence that poor performance is manifest in banks as indicated by low bank performance indicators including: high levels of credit risk, poor quality loans, limited and or inadequate capitalization, operational inefficiencies, higher incidences of non-performing loans, higher levels of liquidity risk, and so on. Although these are mentioned as constraints affecting banks' performance, they are based on a few studies and non-elaborate methods to generate sufficient and valid conclusions. This study therefore becomes an extension of the few studies undertaken with a view to generating more and further information based on empirical evidence on deposit money banks.

The purpose of this paper is to ascertain whether there is any significant relationship between credit risk management and the performance of deposit money banks in Nigeria. The following three null hypotheses were formulated to enable 
us achieve the stated objectives of the paper: (1) Credit risk management does not have any significant impact on the return on equity of deposit money banks in Nigeria; (2) Credit risk management does not have any significant impact on the return on assets of deposit money banks in Nigeria; (3) Credit risk management does not have any significant impact on the return on shareholders' fund of deposit money banks in Nigeria. The rest of the paper is arranged as follows. Section two is the review of related literature, the third section talks about the methodology of the study, section four presents the analysis of data, and finally, section five summarises and concludes the work.

\section{Review of Related Literature}

\subsection{Conceptual and theoretical framework}

Risk to the banker means the perceived uncertainty connected with some event. For example, will the customer renew his or her loan? Will deposit liabilities grow next month? Will the bank's stock price and its earnings increase in the future? Are interest rates going to rise or fall next week and will the bank lose income or value if they do? Bankers may be most interested in achieving high stock values and high profitability, but none can fail to pay attention to the risks they are accepting as well. Bankers are concerned with many types of risks such as credit risk, liquidity risk, market risk, interest rate risk, earnings risk, foreign exchange risk and solvency risk. (Rose,1999; Chen, 2012; Kargi, 2011).

A bank exists not only to accept deposits but also to grant credit facilities and therefore is inevitably exposed to credit risk. In other words, the intermediation function of a bank naturally exposes them to credit risk: credit risk is by far the most significant risk faced by banks and the success of their business depends on accurate measurement and efficient management of credit risk more than any other risks (Gieseche, 2004). Chen and Pan (2012) argue that credit risk is the degree of value fluctuations in debt instruments and derivatives due to changes in the underlying credit quality of borrowers and counterparties. Coyle (2000) defines credit risk as losses from the refusal or inability of credit customers to pay what is owed in full and on time. Credit risk is the exposure faced by banks when a borrower (customer) defaults in honouring debt obligations on due date or at maturity. This risk interchangeably called 'counterparty risk' is capable of putting the bank in distress if not adequately managed. The credit risk management implications are measures employed by banks to avoid or minimize the adverse effect of credit risk. A sound credit risk management framework is crucial for banks so as to enhance profitability and guarantee survival.

The main sources of credit risk include, limited institutional capacity, inappropriate credit policies, volatile interest rates, poor management, inappropriate laws, low capital and liquidity levels, direct lending, massive licensing of banks, poor loan underwriting, laxity in credit assessment, poor lending practices, government interference and inadequate supervision by the central bank. (Kithinji, 2010). An increase in bank credit risk gradually leads to liquidity and solvency problems. Credit risk may increase if the bank lends to borrowers it does not have adequate knowledge about.

Credit risk management maximizes bank's risk adjusted rate of return by maintaining credit risk exposure within acceptable limits in order to provide framework for understanding the impact of credit risk management on banks' profitability (Kargi, 2011). Demirguc-Kunt and Huzinga (1999) opined that credit risk management is in two-fold which includes, the realization that after losses have occurred, the losses become unbearable and the developments in the field of financing commercial paper, securitization and other non-bank competition which push banks to find viable loan borrowers.

Lindergren (1987) argued that the key principles in credit risk management process are sequenced as follows: establishment of a clear structure, allocation of responsibility, processes have to be prioritized and disciplined, responsibilities should be clearly communicated and accountability assigned. The implications for communicated and accountability assigned.

\subsection{Empirical Review}

Kargi (2011) evaluated the impact of credit risk on the profitability of Nigerian banks using financial ratios as measures of bank performance and credit risk data were collected from the annual reports and accounts of sampled banks from 2004-2008 and analyzed using descriptive, correlation and regression techniques. The findings revealed that credit risk management has a significant impact on the profitability of Nigerian banks. It concluded that banks' profitability is inversely influenced by the levels of loans and advances, non-performing loans and deposits thereby exposing them to great risk of illiquidity and distress. Epure and Lafuente (2012) examined bank performance in the presence of risk for Costa-Rican banking industry during 1998-2007. The results showed that performance improvements follow regulatory changes and that risk explains differences in banks and non-performing loans negatively affect efficiency and return on assets while the capital adequacy ratio has a positive impact on the net interest margin.

Kithinji (2010) assessed the effect of credit risk management on the profitability of commercial banks in Kenya. Data on the amount of credit, level of non-performing loans and profits were collected for the period 2004 to 2008. The findings revealed that the bulk of the profits of commercial banks are not influenced by the amount of credit and 
non-performing loans, therefore suggesting that other variables other than credit and non-performing loans impact on profits. Chen and Pan (2012) examined the credit risk efficiency of 34 Taiwanese commercial banks over the period 2005-2008. Their study used financial ratios to assess credit risk and the analysis employed Data Envelopment Analysis (DEA). The credit risk parameters were credit risk technical efficiency (CR-TE), credit risk allocative efficiency (CR-AE), and credit risk cost efficiency (CR-CE). The results indicated that only one bank is efficient in all types of efficiencies over the sample period. Overall, the DEA results show relatively low average efficiency levels in CR-TE, CR-AE and CR-CE in 2008.

Furthermore, Felix and Claudine (2008) investigated the relationship between bank performance and credit risk management focusing on emerging economies. It could be inferred from their findings that return on equity (ROE) and return on assets (ROA) both measuring profitability were inversely related to the ratio of non-performing loans to total loans and advances of financial institutions thereby leading to a decline in profitability.

Ahmed, Takeda and Shawn (1998) in their study found that loan loss provision has a significant positive influence on non-performing loans. For the authors therefore, an increase in loan loss provision indicates an increase in credit risk and deterioration in the quality of loans consequently affecting bank performance adversely.

\section{Methodology}

The research design adopted in this study is the investigative econometric research design as it is meant to investigate and analyse the relationship between two or more variables, namely, credit risk management and performance.

\subsection{Definition of Variables}

\subsubsection{Dependent Variable}

In this study, performance is the dependent variable represented by return on total assets (ROTA), defined as profit after tax divided by total assets; return on equity (ROE), defined as profit after tax divided by equity; and, return on shareholders' fund (ROSF), defined as profit after tax divided by shareholders' fund. The above performance indicators have been used extensively in previous studies and with satisfactory results (Said and Turin, 2011: Okafor, 2012: Aziz, Ibrahim and Isa, 2009 and Ogbulu, 2012).

We have therefore chosen to use return on equity (ROE), return on total assets (ROTA) and return on shareholders' fund (ROSF) as measures of performance representing the dependent variable.

\subsubsection{Independent Variables Credit Risk}

This is the risk of counter-party failure in meeting the payment obligation on the specific date. Credit risk management is an important challenge to deposit money banks in Nigeria and failure on this front leads to failure of banks. We used three measures of credit risk including ratio of non-performing loans to total credit (RNPC) - (that is, default ratio arrived at by dividing non-performing loans and advances by total loans and advances; ratio of non-performing loans to total deposits (RNPD); and ratio of non-performing loans to shareholders' fund (RNPS). (Musyoki and Kadubo, 2012).

\subsection{Model Specification}

Given that the study is aimed at establishing relationships between variables, we employed the multiple regression and correlation analysis expressed functionally as follows:

$$
\begin{array}{r}
\text { ROE }=\mathrm{f}(\text { RNPC, RNPD, RNPS }) \\
\text { ROTA }=\mathrm{f}(\text { RNPC, RNPD, RNPS }) \\
\text { ROSF }=\mathrm{f}(\text { RNPC, RNPD, RNPS })
\end{array}
$$

Econometrically, the regression models can be specified as:

$$
\begin{gathered}
\mathrm{ROE}=\beta_{0}+\beta_{1} \mathrm{RNPC}+\beta_{2} \mathrm{RNPS}+\beta_{3} \mathrm{RNPD}+\mathrm{u}_{1} \\
\mathrm{ROTA}=\beta_{0}+\beta_{1} \mathrm{RNPC}+\beta_{2} \mathrm{RNPS}+\beta_{3} \mathrm{RNPD}+\mathrm{u}_{2} \\
\mathrm{ROSF}=\beta_{0}+\beta_{1} \mathrm{RNPC}+\beta_{2} \mathrm{RNPS}+\beta_{3} \mathrm{RNPD}+\mathrm{u}_{3}
\end{gathered}
$$

where:

$$
\begin{aligned}
& \text { ROE = return on equity } \\
& \text { ROTA } \quad \text { return on assets } \\
& \text { ROSF }=\text { return on shareholders' fund } \\
& \text { RNPC } \quad \text { ratio of non-performing loans to total credit } \\
& \text { RNPS } \quad \text { ratio of non-performing loans to shareholders' fund }
\end{aligned}
$$


RNPD = ratio of non-performing loans to deposit liabilities

$\beta_{0}=$ intercepts

$\beta_{1} \ldots \beta_{3}=$ coefficients to be estimated

$\mathrm{u}_{1} \ldots \mathrm{u}_{3} \quad$ are the error terms respectively.

Data for the study were collected over the period 1989 to 2013 and were sourced from the Central Bank of Nigeria Statistical Bulletin and Nigerian Deposit Insurance Corporation Annual Reports.

\section{Data Presentation}

Table 4.1 below shows the data used for this study - that is, the independent variables as well as the dependent variables from 1990 to 2013.

\begin{tabular}{rrrrrrr}
\hline obs & RNPC & RNPD & RNPS & ROE & ROSF & ROTA \\
\hline 1989 & 40.80 & 0.83 & 356.00 & 65.50 & 23.77 & 76.73 \\
1990 & 44.10 & 0.30 & 344.00 & 63.20 & 25.87 & 17.57 \\
1991 & 39.00 & 0.23 & 222.00 & 26.40 & 21.67 & 7.14 \\
1992 & 45.40 & 0.26 & 299.00 & 9.70 & 3.79 & 1.97 \\
1993 & 41.00 & 0.24 & 380.56 & 33.90 & -8.77 & -5.68 \\
1994 & 43.00 & 0.20 & 567.70 & 12.62 & 1.45 & 0.33 \\
1995 & 32.90 & 0.27 & 496.00 & 44.84 & 0.18 & 1.29 \\
1996 & 33.90 & 0.27 & 419.80 & 56.78 & 2.92 & 1.99 \\
1997 & 25.81 & 0.36 & 253.09 & 96.56 & -0.98 & 3.35 \\
1998 & 19.35 & 0.17 & 89.20 & 86.08 & 7.71 & 4.52 \\
1999 & 25.61 & 0.68 & 102.00 & 80.59 & -1.83 & 4.13 \\
2000 & 21.50 & 0.55 & 92.20 & 99.45 & -11.18 & 3.96 \\
2001 & 16.90 & 0.50 & 77.10 & 114.29 & 0.14 & 4.82 \\
2002 & 21.27 & 0.66 & 85.90 & 41.63 & 0.07 & 2.63 \\
2003 & 21.59 & 0.70 & 89.70 & 29.11 & 0.07 & 2.00 \\
2004 & 23.08 & 0.79 & 105.30 & 27.23 & 0.03 & 2.58 \\
2005 & 20.13 & 0.74 & 57.18 & 4.81 & 0.51 & 0.49 \\
2006 & 7.92 & 0.06 & 22.50 & 17.36 & 6.60 & 2.65 \\
2007 & 8.30 & 0.08 & 22.66 & 36.83 & 6.60 & 5.92 \\
2008 & 6.25 & 0.06 & 16.62 & 34.11 & 7.93 & 4.29 \\
2009 & 32.80 & 0.30 & 135.70 & -64.72 & 13.63 & -9.28 \\
2010 & 15.04 & 0.10 & 250.85 & 16.00 & -0.16 & 3.91 \\
2011 & 4.95 & 0.03 & 17.13 & -0.28 & -0.71 & -0.04 \\
2012 & 3.51 & 0.02 & 14.34 & 22.20 & -0.01 & 2.62 \\
2013 & 4.12 & 0.08 & 20.54 & 23.21 & 0.03 & 2.89 \\
\hline
\end{tabular}

Source: CBN Statistical Bulletin

Table 4.2 Descriptive Statistics

\begin{tabular}{lrrrrrr}
\hline Statistic & RNPD & \multicolumn{1}{c}{ RNPC } & RNPS & ROE & ROSF & ROTA \\
\hline Mean & 0.33 & 24.75 & 188.19 & 39.34 & 3.86 & 3.33 \\
Medium & 0.27 & 22.34 & 103.65 & 31.51 & 0.16 & 2.64 \\
Maximum & 0.79 & 45.40 & 567.70 & 114.29 & 25.87 & 17.57 \\
Minimum & 0.02 & 3.51 & 14.34 & -64.72 & -11.18 & -9.28 \\
Std. Dev. & 0.24 & 13.28 & 165.89 & 39.11 & 9.16 & 5.48 \\
Skewness & 0.57 & 0.01 & 0.78 & -0.21 & 1.10 & 0.69 \\
Kurtosis & 2.09 & 1.85 & 2.43 & 3.63 & 3.75 & 5.34 \\
& & & & & & \\
\hline
\end{tabular}




\begin{tabular}{lrrrrrr}
\hline Jarque-Bera & 2.12 & 1.32 & 2.78 & 0.56 & 5.37 & 7.35 \\
Probability & 0.35 & 0.52 & 0.25 & 0.75 & 0.07 & 0.02 \\
& & & & & & \\
Obs. & 24 & 24 & 24 & 24 & 24 & 24 \\
\hline
\end{tabular}

Source: Researcher's compilation from E-views results

Table 4.2 shows the descriptive statistics of the variables. The results indicate that the mean values are for ratio of non-performing loans to deposit (RNPD) 0.33; for ratio of non-performing loans to total credit (RNPC) 24.75 and for ratio of non-performing loans to shareholders' fund (RNPS) 188.19. The mean value for return on equity (ROE) is 39.34, for return on total assets (ROTA) is 3.86 and for return on shareholders' fund (ROSF) the value is 3.33.The Jarque-Bera statistics indicate that all the variables except ROTA are normally distributed at the 5\% level of significance.

\subsection{Correlation Matrix}

Table 4.3 Correlation matrix

\begin{tabular}{ccccccc}
\hline & RNPD & RNPS & RNPC & ROE & ROTA & ROSF \\
\hline RNPD & 1.000000 & & & & & \\
RNPS & 0.021915 & 1.000000 & & & & \\
RNPC & 0.318201 & 0.816772 & 1.000000 & & & \\
ROE & 0.281146 & 0.052742 & 0.027968 & 1.000000 & & \\
ROTA & 0.368008 & 0.199892 & 0.243599 & 0.293066 & 1.000000 & \\
ROSF & -0.028700 & 0.156224 & 0.343302 & -0.134353 & 0.561380 & 1.000000 \\
\hline
\end{tabular}

Source: E-views results

Table 4.3 presents the correlation matrix showing the degree of correlation between the variables. The table reveals that the variables among themselves have both positive and negative correlations.

\subsection{Level Series Regression Results}

Level series regression was used to test the impact of the independent variables on the dependent variables. In all cases, we regressed the independent variables as indicators of financial management implications on each of the dependent variables as indicators of performance.

However, the results of the Durbin-Watson statistics indicate strong positive autocorrelation in all the models. This indicates that there could be some degree of time dependence in the level series which could lead to spurious regression results, suggesting the need for more rigorous analysis of the stationarity properties of the level series data. Table 4.4 presents the summary results of the estimated level series models.

Table 4.4 Level Series Multiple Regression Results Summary

\begin{tabular}{|c|c|c|c|c|c|c|c|}
\hline \multirow[t]{2}{*}{ Model } & \multicolumn{3}{|l|}{ Variables } & \multicolumn{2}{|c|}{ F-statistic } & \multirow{2}{*}{$\begin{array}{l}\text { Durbin-Watson } \\
\text { Statistic }\end{array}$} & \multirow{2}{*}{$\begin{array}{l}\text { Serial } \\
\text { correlation }\end{array}$} \\
\hline & $\begin{array}{l}\text { Dependent } \\
\text { variable }\end{array}$ & $\begin{array}{l}\text { Independent } \\
\text { variables }\end{array}$ & & F-statistic & Probabi-lity & & \\
\hline 1 & ROE & $\begin{array}{l}\text { RNPC, } \\
\text { RNPS }\end{array}$ & RNPD, & 0.73 & 0.55 & 0.87 & Present \\
\hline 2 & ROTA & $\begin{array}{l}\text { RNPC, } \\
\text { RNPS }\end{array}$ & RNPD, & 0.14 & 0.94 & 1.10 & Present \\
\hline 3 & ROSF & $\begin{array}{l}\text { RNPC, } \\
\text { RNPS }\end{array}$ & RNPD, & 2.40 & 0.1 & 1.06 & Present \\
\hline
\end{tabular}

Source: Author's computation.

\subsection{Unit Root Tests}

Next, the unit root test is carried out to test for the stationarity of the individual variables using the ADF unit root rest.

The results are as presented in Table 4.5. 
Table 4.5 Augmented Dickey-Fuller Unit Root Test Results Summary

\begin{tabular}{|c|c|c|c|}
\hline Variable & $\begin{array}{l}\mathrm{ADF} \text { - Test statistic at } \\
\text { first difference }\end{array}$ & Critical Values & Order of integration \\
\hline RNPC & -6.228475 & $\begin{array}{ll}1 \% & -3.769597 \\
5 \% & -3.004861 \\
10 \% & -2.642242\end{array}$ & $1(1)$ \\
\hline RNPD & -5.561033 & $\begin{array}{lr}1 \% & -3.769597 \\
5 \% & -3.004861 \\
10 \% & -2.642242\end{array}$ & 1(1) \\
\hline RNPS & -3.943577 & $\begin{array}{ll}1 \% & -3.769597 \\
5 \% & -3.004861 \\
10 \% & -2.642242\end{array}$ & 1(1) \\
\hline ROE & -6.087285 & $\begin{array}{ll}1 \% & -3.769597 \\
5 \% & -3.004861 \\
10 \% & -2.642242\end{array}$ & 1(1) \\
\hline ROSF & -4.784789 & $\begin{array}{lr}1 \% & -3.769597 \\
5 \% & -3.004861 \\
10 \% & -2.642242\end{array}$ & 1(1) \\
\hline ROTA & -6.057175 & $\begin{array}{ll}1 \% & -3.769597 \\
5 \% & -3.004861 \\
10 \% & -2.642242\end{array}$ & $1(1)$ \\
\hline
\end{tabular}

\section{Source: Author's computation from E-Views}

Table 4.5 above presents the summary results of the ADF unit root tests. The results show that the null hypotheses of a unit root test for first difference series for all the variables can be rejected at all the critical values indicating that the level series which is largely time-dependent and non-stationary can be made stationary at the first difference and maximum lag of one. Thus, the reduced form model follows an integrating order of 1(1) process and is therefore a stationary process. It also reveals that the test of stationarity in the residuals from the level series regression is significant at all lags. Furthermore, this indicates that the regression is no more spurious but real. That is to say, all the variables are individually stationary and stable.

Having established the stationarity of the individual variables, it is also important to establish the stationarity of the linear combinations of the variables as to whether there could be a long-run or equilibrium relationship between the dependent variables and the independent variables (that is, whether they are co-integrated). We, therefore, tested for co-integration to establish long-run stationary or stable relationship using the Johansen Co-integration test.

Table 4.6 Johansen Co-Integration Test Results

\begin{tabular}{|c|c|c|c|c|c|c|}
\hline \multirow[t]{2}{*}{ Model } & \multicolumn{3}{|l|}{ Variables } & \multicolumn{2}{|c|}{$\begin{array}{l}\text { Number of co-integrating equations at } 5 \\
\text { percent }\end{array}$} & \multirow{2}{*}{$\begin{array}{l}\text { Lag } \\
\text { intervals }\end{array}$} \\
\hline & $\begin{array}{l}\text { Dependent } \\
\text { variable }\end{array}$ & $\begin{array}{l}\text { Independent } \\
\text { variables }\end{array}$ & & Trace tests & Max-eigenvalue test & \\
\hline 1 & ROE & $\begin{array}{l}\text { RNPC, } \\
\text { RNPS }\end{array}$ & RNPD, & 2 & 2 & 1 to 2 \\
\hline 2 & ROTA & $\begin{array}{l}\text { RNPC, } \\
\text { RNPS }\end{array}$ & RNPD, & 2 & 2 & 1 to 2 \\
\hline 3 & ROSF & $\begin{array}{l}\text { RNPC, } \\
\text { RNPS }\end{array}$ & RNPD, & 2 & 2 & 1 to 2 \\
\hline
\end{tabular}

Source: Author's computation.

Table 4.6 shows the summary results of the Johansen Co-integration test employed to test for the long run co-integration relationship between bank performance represented by return on equity (ROE), return on total assets (ROTA), and return on shareholders' fund (ROSF), and asset quality management of deposit money banks. The impact of asset quality management represented by ratio of non-performing loans and advances to total credit (RNPC), ratio of non-performing loans and advances to deposits (RNPD) and ratio of non-performing loans and advances to shareholders' fund (RNPS) on bank performance have two co-integrating equations each for both the trace tests and the maximum-eigenvalue test with one to two lag intervals taken at 5 percent significant level.

\subsection{Test of Hypotheses}

Having established the co-integrating equations, we now establish a link between short-run relationships of the 
dependent and independent variables to the long-run by estimating an error correction model (ECM). The ECM is expressed in such a way that the first difference of each dependent variable is related to both the current and the lagged values of the independent variables, as well as incorporating the error correction coefficient. This, we did by relating the current and the lagged values of both the dependent and independent variables to the dependent variables in order to determine both the current and the lagged effects of the independent variables on the dependent variables.

Each of the variables (both dependent and independent) was lagged three periods. We thereafter successively deleted the most insignificant parameters (redundant variables) one after the other using the Akaike Information Criteria (AIC) and Schwarz Criteria (SC), until we obtained a parsimonious representation of the models containing only parameters that are relatively statistically significant. The Ordinary Least Squares (OLS) estimation method was used as it is an essential component of most other estimation techniques. Furthermore, the OLS remains one of the most commonly used methods in econometric investigations involving large models. Estimates of the preferred specifications were obtained from the over parameterized results using general-to-specific method, and were used to test the hypotheses formulated in this study.

\section{Hypothesis 1}

Credit risk management does not have any significant impact on the return on equity of deposit money banks in Nigeria.

Tables 4.7 shows the results of the parsimonious error correction for the impact on return on equity (ROE) of the independent variables representing credit risk management, namely, ratio of non-performing loans to total credit (RNPC), ratio of non-performing loans to deposits (RNPD), and, ratio of non-performing loans to shareholders' fund (RNPS), each lagged three periods.

Table 4.7 Parsimonious Error Correction Result

\begin{tabular}{|c|c|c|c|c|}
\hline \multicolumn{5}{|c|}{$\begin{array}{l}\text { Dependent Variable: D(ROE) } \\
\text { Method: Least Squares } \\
\text { Sample (adjusted): } 1989-2013 \\
\text { Included observations: } 24 \text { after adjustments }\end{array}$} \\
\hline Variable & Coefficient & Std. Error & t-Statistic & Prob. \\
\hline $\mathrm{C}$ & -13.47714 & 2.818635 & -4.781442 & 0.0014 \\
\hline $\mathrm{D}(\mathrm{ROE}(-1))$ & 0.617011 & 0.162660 & 3.793253 & 0.0053 \\
\hline $\mathrm{D}(\mathrm{ROE}(-3))$ & 0.502800 & 0.094910 & 5.297668 & 0.0007 \\
\hline D(RNPC) & -4.520646 & 0.570902 & -7.918428 & 0.0000 \\
\hline D(RNPC(-1)) & -0.821163 & 0.504938 & -1.626267 & 0.1425 \\
\hline D(RNPC(-2)) & -4.737926 & 0.665333 & -7.121137 & 0.0001 \\
\hline D(RNPD) & 59.22130 & 14.41279 & 4.108941 & 0.0034 \\
\hline $\mathrm{D}(\mathrm{RNPD}(-2))$ & 91.26518 & 17.93700 & 5.088096 & 0.0009 \\
\hline D(RNPD (-3)) & -22.58144 & 16.08110 & -1.404223 & 0.1979 \\
\hline D(RNPS) & 0.094607 & 0.043012 & 2.199538 & 0.0590 \\
\hline $\mathrm{D}(\mathrm{RNPS}(-3))$ & -0.097553 & 0.050659 & -1.925665 & 0.0903 \\
\hline ECM11(-1) & -0.795492 & 0.160625 & -4.952472 & 0.0011 \\
\hline R-squared & 0.973926 & \multirow{4}{*}{\multicolumn{2}{|c|}{ Durbin-Watson Statistic }} & \\
\hline Adjusted R-squared & 0.938073 & & & 2.3687 \\
\hline F-statistic & 27.16491 & & & \\
\hline Prob (F-statistic) & 0.000040 & & & \\
\hline
\end{tabular}

Source: Authors' computation from E-Views

The Parsimonious Error Correction results in Table 4.7 on the impact of credit risk management strategies on return on equity show that R-squared is 0.97 while adjusted R-squared is 0.93 indicating that 93 percent of changes in return on equity are attributable to the combined effect of the ratio of non-performing loans to total credit (RNPC), the ratio of non-performing loans to deposits (RNPD) and the ratio of non-performing loans to shareholders' fund (RNPS). Also, from the table, we see that the ratio of non-performing loans to total credit has a t-statistic of -7.92 with a probability value of 0.000 which is statistically significant indicating that it has a significant relationship with return on equity. The ratio of non-performing loans to deposits shows a similar relationship with return on equity with a t-statistic of 4.10 and a probability value of 0.003 . The ratio of non-performing loans to shareholders' fund has a t-statistic of 2.2 and a probability of 0.059 which is still statistically significant, especially when taken at 10 percent.

Overall, the results show that the F-statistic is 27.16 with a probability value of 0.000 indicating that the combined impact of the independent variables on bank performance represented by return on equity is statistically significant. We 
therefore reject the null hypothesis, and conclude that the credit risk management strategies adopted by deposit money banks in Nigeria have significant impact on their return on equity.

Furthermore, the Error Correction Co-efficient of -0.795492 is appropriately signed, being negative and also significant at $5 \%$ level of significance. The co-efficient shows that the speed of adjustment of the model is approximately 79.55 percent annually due to any deviation from equilibrium.

\section{Hypothesis 2}

Credit Risk Management Strategies adopted by deposit money banks in Nigeria do not have any significant impact on their return on total assets (ROTA)

Tables 4.8 presents the results of the parsimonious error correction for the impact on return on total assets (ROTA) of the independent variables representing credit risk management, namely, ratio of non-performing loans to total credit (RNPC), ratio of non-performing loans to deposits (RNPD), and ratio of non-performing loans to shareholders' fund (RNPS) each lagged three periods.

Table 4.8 Parsimonious Error Correction Result

\begin{tabular}{|c|c|c|c|c|}
\hline \multicolumn{5}{|c|}{ Dependent Variable: D(ROTA) } \\
\hline \multicolumn{5}{|c|}{ Method: Least Squares } \\
\hline \multicolumn{5}{|c|}{ Sample (adjusted): 1989- 2013} \\
\hline \multicolumn{5}{|c|}{ Included observations: 24 after adjustments } \\
\hline Variable & Coefficient & Std. Error & $\mathrm{t}$-Statistic & Prob. \\
\hline $\mathrm{C}$ & -1.377227 & 0.454913 & -3.027455 & 0.0164 \\
\hline D(ROTA(-1)) & 0.495217 & 0.247865 & 1.997929 & 0.0808 \\
\hline D(ROTA(-2)) & 0.806276 & 0.144350 & 5.585552 & 0.0005 \\
\hline $\mathrm{D}(\mathrm{RNPC})$ & -0.559380 & 0.106930 & -5.231284 & 0.0008 \\
\hline $\mathrm{D}(\mathrm{RNPC}(-2))$ & 0.122601 & 0.089389 & 1.371543 & 0.2074 \\
\hline $\mathrm{D}(\mathrm{RNPC}(-3))$ & -0.282991 & 0.081761 & -3.461194 & 0.0086 \\
\hline $\mathrm{D}(\mathrm{RNPD})$ & 8.658735 & 2.626743 & 2.534978 & 0.0350 \\
\hline $\mathrm{D}(\mathrm{RNPD}(-1))$ & -6.619032 & 1.952671 & -3.389732 & 0.0095 \\
\hline $\mathrm{D}(\mathrm{RNPD}(-3))$ & 7.917764 & 2.370035 & 3.340780 & 0.0102 \\
\hline D(RNPS) & 0.025648 & 0.009306 & 2.755970 & 0.0248 \\
\hline $\mathrm{D}(\mathrm{RNPS}(-3))$ & -0.007485 & 0.007920 & -0.945072 & 0.3723 \\
\hline ECM12(-1) & -0.986727 & 0.259771 & -3.798442 & 0.0052 \\
\hline R-squared & 0.963765 & & & \\
\hline Adjusted R-squared & 0.913942 & Durbin-W & son Statistic & 1.834 \\
\hline F-statistic & 19.34371 & & & \\
\hline Prob (F-statistic) & 0.000143 & & & \\
\hline
\end{tabular}

Source: Authors' computation from E-views

The Parsimonious Error Correction results in Table 4.8 on the impact of credit risk management strategies on return on total assets of deposit money banks reveal that all the three independent variables, namely ratio of non-performing loans to total credit, ratio of non-performing loans to deposits, and ratio of non-performing loans to shareholders, respectively, have a significant impact on return on total assets.

The overall result reveals that R-squared is 0.96 and adjusted R-squared is 0.91 indicating that 91 percent of the variations in return on total assets could be explained by the combined effect of changes in the return on total assets itself on the long run, management of non-performing loans and advances in relation to total loans and advances, deposit liabilities and shareholders' fund. 
F-statistic is 19.34 with a probability value of 0.000 indicating that the combined effect of return on total assets itself on the long run, management of non-performing loans and advances in relation to total loans and advances, deposit liabilities and shareholders' fund respectively, have significant impact on bank performance represented by return on total assets at the $5 \%$ level of significance We therefore reject hypothesis 2 and conclude that the credit risk management strategies adopted by deposit money banks in Nigeria have a significant impact on their return on total assets.

The Error Correction Co-efficient of -0.986727 is appropriately signed, being negative and also significant at 5\% level of significance. The co-efficient shows that the speed of adjustment of the model is approximately 98.67 percent annually due to a deviation from equilibrium.

\section{Hypothesis 3}

Credit Risk Management Strategies adopted by deposit money banks in Nigeria do not have any significant impact on their return on shareholders' fund (rosf).

Tables 4.9 shows the results of the parsimonious error correction for the impact on return on shareholders' fund (rosf) of the independent variables representing credit risk management, namely, ratio of non-performing loans to total credit (RNPC), ratio of non-performing loans to deposits (RNPD) and ratio of non-performing loans to shareholders' fund (RNPS) each lagged three periods.

Table 4.9 Parsimonious Error Correction Result

\begin{tabular}{|c|c|c|c|c|}
\hline \multicolumn{5}{|c|}{$\begin{array}{l}\text { Dependent Variable: D(ROSF) } \\
\text { Method: Least Squares } \\
\text { Sample (adjusted): } 1989-2013 \\
\text { Included observations: } 24 \text { after adjustments }\end{array}$} \\
\hline Variable & Coefficient & Std. Error & t-Statistic & Prob. \\
\hline $\mathrm{C}$ & -2.378057 & 1.138168 & -2.089372 & 0.0701 \\
\hline $\mathrm{D}(\mathrm{ROSF}(-3))$ & 0.335188 & 0.182891 & 1.832717 & 0.1042 \\
\hline $\mathrm{D}(\mathrm{RNPC})$ & -0.118915 & 0.240910 & -0.493607 & 0.6348 \\
\hline $\mathrm{D}(\mathrm{RNPC}(-2))$ & -0.697448 & 0.210156 & -3.318722 & 0.0106 \\
\hline D(RNPC(-3)) & -0.617477 & 0.229434 & -2.691305 & 0.0274 \\
\hline D(RNPD) & -7.260670 & 6.621466 & -1.096535 & 0.3048 \\
\hline D(RNPD (-1)) & -13.21209 & 5.071463 & -2.605184 & 0.0314 \\
\hline D(RNPD (-3)) & 17.30904 & 7.082555 & 2.443898 & 0.0403 \\
\hline D(RNPS) & -0.019975 & 0.015373 & -1.299328 & 0.2300 \\
\hline $\mathrm{D}(\mathrm{RNPS}(-2))$ & 0.087882 & 0.020612 & 4.263732 & 0.0027 \\
\hline $\mathrm{D}(\mathrm{RNPS}(-3))$ & -0.043573 & 0.020091 & -2.168725 & 0.0619 \\
\hline ECM13(-1) & -0.284001 & 0.264035 & -1.075621 & 0.3135 \\
\hline R-squared & 0.855375 & \multirow{4}{*}{\multicolumn{2}{|c|}{ Durbin-Watson Statistic }} & \\
\hline Adjusted R-squared & 0.656515 & & & 1.9686 \\
\hline F-statistic & 4.301397 & & & \\
\hline Prob (F-statistic) & 0.024028 & & & \\
\hline
\end{tabular}

Source: E-views econometrics output

The Parsimonious Error Correction results in Table 4.9 on the impact of credit risk management strategies on return on shareholders' fund reveal that none of the independent variables is statistically significant in the current period.

The overall result reveals that R-squared is 0.86 (with adjusted R-squared of 0.66) indicating that 66 percent of the variations in return on shareholders' fund could be explained by the combined effect of changes in the return on shareholders' fund itself, management of non-performing loans and advances in relation to total loans and advances, deposit liabilities and shareholders' fund.

F-statistic is 4.301 with a probability value of 0.024 indicating that the combined effect of return on shareholders' fund itself, management of non-performing loans and advances in relation to total loans and advances, deposit liabilities and shareholders' fund respectively, have significant impact on bank performance represented by return on shareholders' fund at 5 percent. Consequently, we reject the null hypothesis and conclude that the management of credit risk has a significant impact on return on shareholders' fund.

Furthermore, the Error Correction Co-efficient of -.284001 is appropriately signed, being negative and also significant at $5 \%$ level of significance. The co-efficient shows that the speed of adjustment of the model is approximately 28.4 
percent annually due to a deviation from equilibrium.

\subsection{Pair-wise Granger Causality Test Results}

The purpose of the pair-wise granger causality test is to ascertain the direction of causality between each of the independent variables and the dependent variables. This is also to determine whether a specific variable or group of variables play any significant role in the determination of other variables in the Vector Error Correction (VECM). It tests whether an endogenous variable can be treated as exogenous and was done by examining the statistical significance of the lagged error correction terms by applying separate t-tests on the adjustment coefficients.

A shock to any variable in the VEC model not only directly affects the variable, but is also transmitted to all of the other endogenous variables through the dynamic (lag) structure of the VECM. Apriori expectation is that the independent variables should cause changes in the dependent variable both on the short-run and on the long-run. But in reality, the relationship could be the other way round.

Table 4.10 shows the direction of causality of changes in the variables representing credit risk management and the variables representing bank performance.

Table 4.10 Pair-wise Granger Causality Tests Results

\begin{tabular}{llll}
\hline Pairwise Granger Causality Tests & & & \\
Sample: 19902013 & & & \\
Lags: 2 & & & \\
Null Hypothesis & Obs & F-statistic & Prob \\
\hline ROE does not cause RNPC & 24 & 1.65009 & 0.2213 \\
RNPC does not cause ROE & & 0.98144 & 0.3950 \\
ROSF does not cause RNPC & 24 & 1.76868 & 0.2005 \\
RNPC does not cause ROSF & & 0.21232 & 0.8108 \\
ROTA does not cause RNPC & 24 & 3.00350 & 0.0764 \\
RNPC does not cause ROTA & & 0.03725 & 0.9635 \\
ROE does not cause RNPD & 24 & 4.47404 & $0.0275^{*}$ \\
RNPD does not cause ROE & & 0.11801 & 0.8894 \\
ROSF does not cause RNPD & 24 & 1.59508 & 0.2318 \\
RNPD does not cause ROSF & & 0.74693 & 0.4887 \\
ROTA does not cause RNPD & 24 & 0.37574 & 0.6923 \\
RNPD does not cause ROTA & & 0.56987 & 0.5760 \\
ROE does not cause RNPS & 24 & 2.61408 & 0.1024 \\
RNPS does not cause ROE & & 1.03854 & 0.3754 \\
ROSF does not cause RNPS & 24 & 1.52594 & 0.2458 \\
RNPS does not cause ROSF & & 0.06530 & 0.9370 \\
ROTA does not cause RNPS & 24 & 15.6737 & $0.0001^{*}$ \\
RNPS does not cause ROTA & & 0.56794 & 0.5771 \\
\hline
\end{tabular}

Source: Authors' computation from E-views7.1.

The Granger causality test results in Table 4.10 reveals the direction of causality between the various variables representing bank performance (ROE, ROTA, ROSF) and credit risk management variables. The results above indicate that there is a unidirectional granger causality relationship running from ROE to RNPD and also from ROTA to RNPS respectively.

\subsection{Impulse Response Analysis and Forecast Error Variance Decomposition}

The results of the impulse response analysis and forecast error variance decomposition are presented in the following sections:

\subsubsection{Forecast of Impact of Credit Risk Management on Bank Performance}

Results of impulse response and variance decomposition forecast as presented in Figure 1 are on the impact of credit risk management on bank performance. The results show that the ratio of non-performing loans to total loans and advances is forecast to explain only between 17.01 percent to 17.6 percent of future changes in return on equity, 13.5 percent to 14.4 percent to future changes in return on total assets, and tends to be stable around 5.5 percent to future changes in return on shareholders' fund from the $5^{\text {th }}$ to the $10^{\text {th }}$ years. Whereas, ratio of non-performing loans and advances to deposit is found to explain between 0.68 percent and 2.74 percent of future changes in return on equity, 6.4 to 6.8 percent to future changes in return on total assets and 4.13 to 4.42 percent to future changes in return on 
shareholders' fund for the same time frame. The ratio of non-performing loans to shareholders' fund is seen to explain between 13.5 to 14.2 percent of future changes in return on equity, 5.6 to 6.3 percent to future changes in return on total assets; and, 6.4 to 6.8 percent to future changes in return on shareholders' fund for the same time frame.

\subsection{Discussion of Findings}

In this study, we have analysed the impact of credit risk management indicators on the performance of deposit money banks. To achieve the objectives of the study, we formulated three hypotheses to test the impact of each of the credit risk management indicators used in this study on each of the three performance indicators. Three models were therefore formulated to test credit risk management indicators against each of the three performance indicators, namely, return on equity (ROE), return on total assets (ROTA), and return on shareholders' fund (ROSF). The essence is to ascertain whether the credit risk management indicators impact significantly on each or all of the three performance indicators in the same way or otherwise.

The results show that using the ratio of non-performing loans to total credit, the ratio of non-performing loans to deposits and the ratio of non-performing loans to shareholders' fund to represent credit risk management strategies, there is a significant impact on all the three performance indicators used in this study, namely return on equity, return on total assets and return on shareholders' fund.

Felix and Claudine (2008) investigated the relationship between bank performance and credit risk management and concluded that return on equity (ROE) and return on assets (ROA) both measuring profitability were inversely related to the ratio of non-performing loans to total loans of financial institutions thereby leading to a decline in profitability.

\section{Conclusion and Recommendations}

This work is an analysis of the impact of credit risk management on the performance of deposit money banks. In summary, the findings demonstrate succinctly, that the selected credit risk management indicators under study significantly affect the performance of deposit money banks in Nigeria; (that notwithstanding the relationships established between the credit risk management indicators and performance of deposit money banks, the measure of relationship varies among the different measures (indicators) of performance; namely, return on equity, return on total assets, and return on shareholders' fund. However, we report that there is no significant granger causality relationship between the various credit risk management indicators and the various measures of performance except for a uni-directional granger causality relationship from ROE to RNPD and from ROTA to RNPS respectively.

Based on the foregoing, we conclude that there is a significant relationship between the various credit risk management indicators employed in this study for deposit money banks and their financial performance in Nigeria.

\subsection{Recommendations}

Based on the findings of this paper, we recommend that deposit money banks in Nigeria should improve on their credit risk management policies in order to significantly improve (reduce) the ratio of non-performing loans to deposits, to total credits and to shareholders' fund respectively. This, they can do by adhering strictly to the prudential guidelines and employing international best practices in credit administration, particularly, following the Basel principles. Finally, the regulatory authorities should also pay more attention to compliance by deposit money banks to the relevant provisions of the Banks and Other Financial Institutions Act (BOFIA) 1999 and the prudential guidelines issued by the Central Bank of Nigeria from time to time.

\section{References}

Ahmed, A. S., Takeda, C., \& Shawn, T. (1998). Bank loan loss provision: A re-examination of capital management and signaling effects, Working Paper, Department of Accounting, Syracuse University, 1-37.

Ahmad, N. H., \& Ariff, M. (2007). Multi-country study of bank credit risk determinants, International Journal of Banking and Finance, 5(1), 135-152.

Aziz, N. A., Ibraham, I. I., \& Isa, M. B. (2009). The impact of Non-performing loans (NPL) towards profitability (ROA,ROE, and NPM). Research report to the research management institute, India.

Basel Committee on Banking Supervision (2001). Risk management practices and regulatory capital: cross-sectional comparison (available at www.bis.org)

CBN. (2013). Statistical Bulletin, Abuja.

Annual Report and Statement of Accounts for various years, Abuja, Government Printer.

Chen, J. (2004). Non-performing Loan Securitization in the People's Republic of China, Stanford University, Palo Alto, $\mathrm{CA}$ 
Chen, K. \& Pan, C. (2012). An empirical study of credit risk efficiency of banking industry in Taiwan, Web Journal of Chinese Management Review, 15(1), 1-16.

Coyle, B. (2000). Framework for credit risk management, Chartered Institute of Bankers, United Kingdom

Epure, M., \& Lafuente, I. (2012). Monitoring bank performance in the presence of risk, Barcelona GSE Working Paper Series, 61.

Ezeoha, A. E. (2011). Banking consolidation, credit crisis and asset quality in a fragile banking system: some evidence from the Nigerian banking data. Journal of financial regulation and compliance, 19(1), 33-44.

Felix, A. T., \& Claudine, T. N. (2008). Bank performance and credit risk management, Unpublished Masters Dissertation in Finance, University of Skovde.

Gil-Diaz, F. (2008). The Origin of Mexico's 1994 Financial Crisis, The Cato Journal, 17(3). http://www.cato.org/pubs/journal/cj, on 28 November 2014

Kargi, H. S. (2011). Credit risk and the performance of Nigerian banks, Ahmadu Bello University, Zaria.

Kithinji, A. M. (2010). Credit risk management and profitability of commercial banks in Kenya, School of Business, University of Nairobi, Nairobi.

Kolap, T. F., Ayeni, R. K., \& Oke, M. O. (2012) Credit risk and commercial banks performance in Nigeria: A panel model approach. Australian Journal of Business and Management Research, 2(2), 31-38.

Lindgren, H. (1987). Banks, investment company, banking firms, Stockholm Enskilda Bank (1924-1945), Institute for Research in Economic History, Stockholm School of Economics, Stockholm.

NDIC annual reports and financial statements, (various years).

Nworuh, G. E. (2001). Applied quantitative techniques for management decisions. Bon Associates.

Ogbulu, O. M. (2012). All-Asset market portfolio and the risk-return behaviour of assets: Evvidence from the Nigerian capital market, Saarbrucken, Germany, LAP Lambert Academic Publishing.

Quantitative Micro Software, LCC (2010). Eviews user's guide. 4521 Campus Drive, USA.

Quantitative Micro Software, LCC (2010). Eviews user's guide 2. 4521 Campus Drive, USA.

Rose, P. S. (1999). Commercial bank management. Fourth edition. McGraw-hill International editions. Finance series. 


\section{Appdiex I}
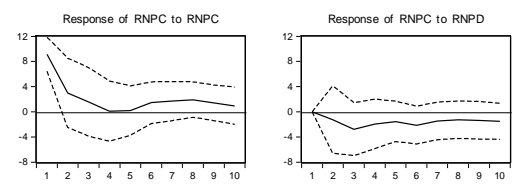

Response to Cholesky One S.D. Innovations \pm 2 S.E.
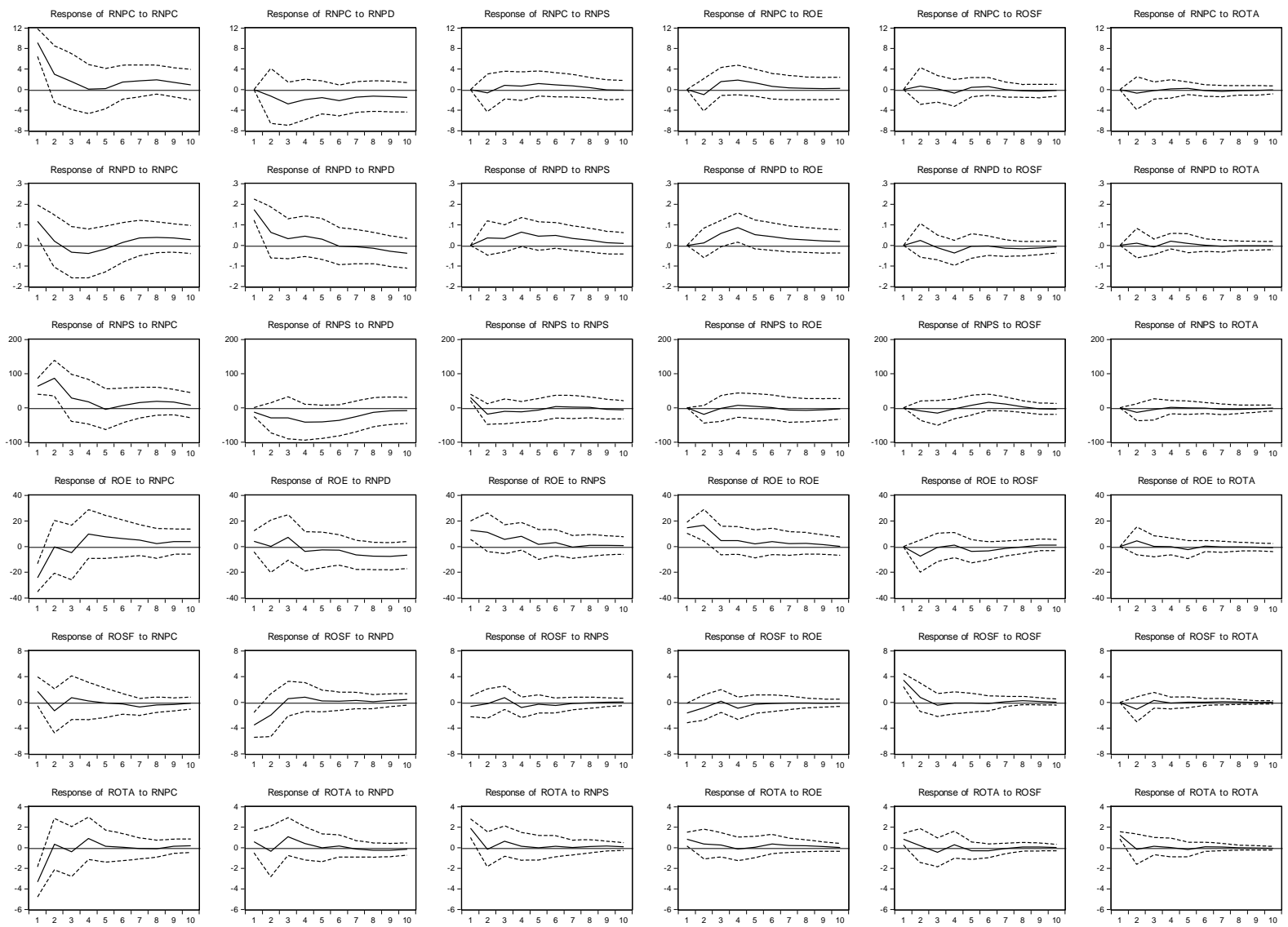

Figure 1

Source: E-Views software output.

\section{$(\mathrm{ccc}) \mathrm{EY}$}

This work is licensed under a Creative Commons Attribution 3.0 License. 